\title{
Design and characterization of chitosan-containing mucoadhesive buccal patches of propranolol hydrochloride
}

VISHNU M. PATEL*

BHUPENDRA G. PRAJAPATI

MADHABHAI M. PATEL

\section{S. K. Patel College of Pharmaceutical Education and Research, Ganpat Vidyanagar, Kherva-382711, Mehsana Gujarat, India}

\begin{abstract}
Mucoadhesive buccal patches containing propranolol hydrochloride were prepared using the solvent casting method. Chitosan was used as bioadhesive polymer and different ratios of chitosan to PVP K-30 were used. The patches were evaluated for their physical characteristics like mass variation, drug content uniformity, folding endurance, ex vivo mucoadhesion strength, ex vivo mucoadhesion time, surface $\mathrm{pH}$, in vitro drug release, and in vitro buccal permeation study. Patches exhibited controlled release for a period of $7 \mathrm{~h}$. The mechanism of drug release was found to be non-Fickian diffusion and followed the first-order kinetics. Incorporation of PVP K-30 generally enhanced the release rate. Swelling index was proportional to the concentration of PVP K-30. Optimized patches (F4) showed satisfactory bioadhesive strength of $9.6 \pm 2.0 \mathrm{~g}$, and ex vivo mucoadhesion time of 272 minutes. The surface $\mathrm{pH}$ of all patches was between 5.7 and 6.3 and hence patches should not cause irritation in the buccal cavity. Patches containing $10 \mathrm{mg}$ of drug had higher bioadhesive strength with sustained drug release as compared to patches containing $20 \mathrm{mg}$ of drug. Good correlation was observed between the in vitro drug release and in vitro drug permeation with a correlation coefficient of 0.9364 . Stability study of optimized patches was done in human saliva and it was found that both drug and buccal patches were stable.
\end{abstract}

Keywords: mucoadhesion, buccal patch, propranolol hydrochloride, buccal delivery, chitosan

Buccal mucosa is an attractive route for systemic delivery of drugs since it is relatively permeable with a rich blood supply (1). A drug can be easily applied and localized to the application site, and can be removed from there if necessary. Attempt has been made earlier to formulate various mucoadhesive buccal devices, including tablets (2), films (3), patches (4), disks (5), strips (6), ointments (7) and gels (8). Buccal patches are highly flexible and thus much more readily tolerated by the patient than tablets. Patches also ensure more accurate dosing of the drug compared to gels and ointments.

\footnotetext{
* Correspondence, e-mail: mmalai2003@yahoo.co.in
} 
During the last decade, bioadhesive polymers received considerable attention as platforms for buccal controlled delivery due to their ability to localize the dosage form in specific regions to enhance drug bioavailability (9). In the present study, the natural bioadhesive polymer chitosan was selected (10) for the development of controlled release buccal mucoadhesive devices. Chitosan is the $N$-deacetylated product of the polysaccharide chitin (11). Chitosan is gaining increasing importance in the pharmaceutical field due to its good biocompatibility, after both intravenous and oral administration, and its non-toxicity and biodegradable (12). From the technological point of view, chitosan has also been demonstrated to be a promising matrix carrier for sustained drug release (13) and it possesses excellent film-forming properties (14). In spite of this, only a few studies have so far been performed on the usefulness of chitosan films as drug delivery systems (15).

Propranolol hydrochloride, a non-selective -adrenergic blocking agent, has been widely used in the treatment of hypertension, angina pectoris and many other cardiovascular disorders (16).

The present study was an attempt to develop chitosan-containing mucoadhesive buccal patches to ensure satisfactory release of propranolol hydrochloride for prolonged periods. The influence of Polyvinylpyrrolidone K-30 (PVP K-30) and drug concentration on the drug release and mucoadhesive performance on sheep buccal patches was investigated.

\section{EXPERIMENTAL}

\section{Materials}

Propranolol hydrochloride (99.86\% purity) was a gift sample from Sarabhai Chemicals Ltd., India. Chitosan (140 cps, 85\% deacetylation) was a gift sample from the Central Institute of Fisheries Technology, India. PVP K-30 (S. D. Fine Chemicals, India) was obtained from a commercial source. All other reagents and chemicals used were of analytical reagent grade.

\section{Preparation of mucoadhesive buccal patches}

Patches containing different drug and chitosan proportions were prepared by the solvent casting method (17). One g of chitosan was dissolved in $100 \mathrm{~mL} \mathrm{1.5 \%} \mathrm{(V/V)} \mathrm{ace-}$ tic acid under occasional stirring for $48 \mathrm{~h}$. The resulting viscous chitosan solution was filtered through nylon gauze to remove debris and suspended particles. To improve patch performance and release characteristics, a water-soluble hydrophilic additive, PVP K-30, was added in different concentrations. The drug and PVP K-30 were added into the chitosan solution under constant stirring. Propylene glycol $(5 \%, V / V)$ was added into the solution as plasticizer under constant stirring. This viscous solution was left overnight at room temperature to ensure a clear, bubble-free solution. The solution was poured into a glass Petri dish (16 cm diameter) and allowed to dry at ambient temperature till a flexible film was formed. Dried films were carefully removed, checked for any imperfections or air bubbles and cut into patches of $16 \mathrm{~mm}$ in diameter, containing $10 \mathrm{mg}$ or $20 \mathrm{mg}$ of drug per patch. The patches were packed in aluminum foil and stored in an airtight glass container to maintain the integrity and elasticity of the patches. Table I shows the composition of different buccal patches. 
V. M. Patel et al:: Design and characterization of chitosan-containing mucoadhesive buccal patches of propranolol hydrochloride, Acta Pharm. 57 (2007) 61-72.

Table I. Composition of chitosan buccal patches of propranolol hydrochloride

\begin{tabular}{lcccccccc}
\hline \multirow{2}{*}{ Component } & \multicolumn{7}{c}{ Batch code } \\
\cline { 2 - 9 } & Placebo & F1 & F2 & F3 & F4 & F5 & F6 & F7 \\
\hline Propranolol hydrochloride $(\mathrm{mg})$ & - & 640 & 640 & 640 & 640 & 640 & 640 & 320 \\
Chitosan $(\mathrm{mg})$ & 1000 & 1000 & 1000 & 1000 & 1000 & 1000 & 1000 & 1000 \\
PVP K-30 $(\mathrm{mg})$ & - & - & 100 & 150 & 175 & 200 & 225 & 175 \\
Acetic acid 1\% $(\mathrm{m} / \mathrm{m})$ & 1.5 & 1.5 & 1.5 & 1.5 & 1.5 & 1.5 & 1.5 & 1.5 \\
Propylene glycol $(\%, \mathrm{~m} / \mathrm{m})$ & - & 5 & 5 & 5 & 5 & 5 & 5 & 5 \\
\hline
\end{tabular}

\section{Mass uniformity and folding endurance}

Mass uniformity was tested in 10 different randomly selected patches from each batch and patch thickness was measured at 5 different randomly selected spots using a screw gauge.

Folding endurance of the patches was determined by repeatedly folding one patch at the same place till it broke or folded up to 200 times without breaking (18).

\section{Swelling study}

Buccal patch was weighed, placed in a $2 \%$ agar gel plate (29) and incubated at $37 \pm 1$ ${ }^{\circ} \mathrm{C}$. At regular one-hour time intervals (to $3 \mathrm{~h}$ ), the patch was removed from the Petri dish and excess surface water was removed carefully using the filter paper. The swollen patch was then reweighed and the swelling index was calculated (19). The experiments were carried out in triplicate and average values were reported.

\section{Content uniformity}

Drug content uniformity was determined by dissolving the patch by homogenization in $100 \mathrm{~mL}$ of an isotonic phosphate buffer ( $\mathrm{pH}$ 6.8) for $8 \mathrm{~h}$ under occasional shaking. The $5 \mathrm{~mL}$ solution was taken and diluted with isotonic phosphate buffer $\mathrm{pH} 6.8$ up to 20 $\mathrm{mL}$, and the resulting solution was filtered through a $0.45 \mu \mathrm{m}$ Whatman filter paper. The drug content was then determined after proper dilution at $290 \mathrm{~nm}$ using a UV-spectrophotometer (Shimadzu, SPD-10 A VP, Japan) (20). The experiments were carried out in triplicate and average values were reported.

\section{Ex vivo mucoadhesive strength}

Fresh sheep buccal mucosa was obtained from a local slaughterhouse and used within $2 \mathrm{~h}$ of slaughter. The mucosal membrane was separated by removing the underlying fat and loose tissues. The membrane was washed with distilled water and then with isotonic phosphate buffer $\mathrm{pH} 6.8$ at $37^{\circ} \mathrm{C}$. Bioadhesive strength of the patch was measured $(n=3)$ on a modified physical balance using the method described by Gupta et al. (21). Fresh sheep buccal mucosa was cut into pieces and washed with isotonic phosphate 
V. M. Patel et al:: Design and characterization of chitosan-containing mucoadhesive buccal patches of propranolol hydrochloride, Acta Pharm. 57 (2007) 61-72.

buffer $\mathrm{pH}$ 6.8. A piece of buccal mucosa was tied to the open mouth of a glass vial, filled completely with isotonic phosphate buffer $\mathrm{pH}$ 6.8. The glass vial was tightly fitted in the center of a glass beaker filled with isotonic phosphate buffer ( $\mathrm{pH} 6.8,37 \pm 1{ }^{\circ} \mathrm{C}$ ). The patch was stuck to the lower side of the rubber stopper with cyanoacrylate adhesive. The mass, in gramms, required to detach the patch from the mucosal surface gave the measure of mucoadhesive strength. The following parameters were calculated from the bioadhesive strength:

$$
\begin{gathered}
\text { force of adhesion }(\mathrm{N})=\frac{\text { bioadhesive strength } \times 9.81}{1000} \\
\text { bond strength }\left(\mathrm{N} \mathrm{m}^{-2}\right)=\frac{\text { force of adhesion }}{\text { disk surface area }}
\end{gathered}
$$

The results are reported in Table II.

\section{Ex vivo mucoadhesion time}

The ex vivo mucoadhesion time was evaluated $(n=3)$ after application of the patches onto freshly cut sheep buccal mucosa (22). The fresh sheep buccal mucosa was fixed in the inner side of the beaker, above $2.5 \mathrm{~cm}$ from the bottom, with cynoacrylate glue. One side of each patch was wetted with one drop of isotonic phosphate buffer pH 6.8 and pasted to the sheep buccal mucosa by applying a light force with a fingertip for 30 seconds. The beaker was filled with $500 \mathrm{~mL}$ of isotonic phosphate buffer $\mathrm{pH} 6.8$ and was kept at $37 \pm 1{ }^{\circ} \mathrm{C}$. After 2 minutes, a $50 \mathrm{rpm}$ stirring rate was applied to simulate the buccal cavity environment, and patch adhesion was monitored up to $12 \mathrm{~h}$. The time required for the patch to detach from the sheep buccal mucosa was recorded as the mucoadhesion time. The results are shown in Table III.

Table II. Bioadhesive parameters of propranolol hydrochloride buccal patches F1 to F7

\begin{tabular}{lccc}
\hline Batch code & Bioadhesive strength $(\mathrm{g})^{\mathrm{a}}$ & Force of adhesion $(\mathrm{N})$ & Bond strength $\left(\mathrm{N} \mathrm{m}^{-2}\right)$ \\
\hline Placebo & $21.5 \pm 1.8$ & 0.21 & 1049 \\
F1 & $12.6 \pm 2.4$ & 0.12 & 615 \\
F2 & $11.4 \pm 1.3$ & 0.11 & 556 \\
F3 & $10.1 \pm 1.2$ & 0.10 & 493 \\
F4 & $9.6 \pm 2.0$ & 0.10 & 469 \\
F5 & $4.8 \pm 0.9$ & 0.05 & 234 \\
F6 & $2.9 \pm 0.7$ & 0.03 & 141 \\
F7 & $13.5 \pm 0.7$ & 0.13 & 659 \\
\hline
\end{tabular}

a Mean $\pm \mathrm{SD}, n=3$. 
V. M. Patel et al:: Design and characterization of chitosan-containing mucoadhesive buccal patches of propranolol hydrochloride, Acta Pharm. 57 (2007) 61-72.

Table III. Parameters of chitosan buccal patches of propranolol hydrochloride ${ }^{a}$

\begin{tabular}{lcccccc}
\hline $\begin{array}{l}\text { Batch } \\
\text { code }\end{array}$ & $\begin{array}{c}\text { Mass } \\
(\mathrm{mg})\end{array}$ & $\begin{array}{c}\text { Thickness } \\
(\mathrm{mm})\end{array}$ & $\begin{array}{c}\text { Drug } \\
\text { content }(\%)\end{array}$ & $\begin{array}{c}\text { Ex vivo } \\
\text { mucoadhesion } \\
\text { time }(\mathrm{min})\end{array}$ & $\begin{array}{c}\text { Surface } \\
\mathrm{pH}\end{array}$ & $\begin{array}{c}\text { Folding } \\
\text { endurance }\end{array}$ \\
\hline Placebo & $48 \pm 1$ & $0.31 \pm 0.08$ & 0 & $705 \pm 6$ & $6.32 \pm 0.21$ & $212 \pm 17$ \\
F1 & $72 \pm 1$ & $0.51 \pm 0.07$ & $99.34 \pm 0.50$ & $300 \pm 7$ & $5.90 \pm 0.18$ & $188 \pm 12$ \\
F2 & $74 \pm 1$ & $0.53 \pm 0.05$ & $98.90 \pm 1.11$ & $285 \pm 6$ & $5.70 \pm 0.13$ & $176 \pm 10$ \\
F3 & $76 \pm 1$ & $0.55 \pm 0.09$ & $100.38 \pm 0.41$ & $270 \pm 9$ & $6.02 \pm 0.14$ & $174 \pm 14$ \\
F4 & $80 \pm 0$ & $0.56 \pm 0.04$ & $99.65 \pm 0.20$ & $272 \pm 6$ & $5.93 \pm 0.02$ & $168 \pm 20$ \\
F5 & $82 \pm 1$ & $0.57 \pm 0.02$ & $99.68 \pm 0.15$ & $195 \pm 7$ & $5.81 \pm 0.12$ & $160 \pm 18$ \\
F6 & $84 \pm 1$ & $0.58 \pm 0.04$ & $99.00 \pm 0.62$ & $165 \pm 4$ & $6.05 \pm 0.14$ & $152 \pm 22$ \\
F7 & $68 \pm 1$ & $0.43 \pm 0.01$ & $99.95 \pm 0.26$ & $430 \pm 6$ & $5.92 \pm 0.05$ & $223 \pm 12$ \\
\hline
\end{tabular}

a Mean $\pm \mathrm{SD}, n=3$.

\section{Surface $p H$ study}

The method adopted by Bottenberg et al. (23) was used to determine the surface pH of the patches. A combined glass electrode was used for this purpose. The patches were allowed to swell by keeping them in contact with $1 \mathrm{~mL}$ of distilled water $(\mathrm{pH} 6.5 \pm 0.1)$ for $2 \mathrm{~h}$ at room temperature, and $\mathrm{pH}$ was noted down by bringing the electrode in contact with the surface of the patch, allowing it to equilibrate for 1 minute.

\section{In vitro release}

The USP 23 (24) rotating paddle method was used to study the drug release from buccal patches. The dissolution medium consisted of $200 \mathrm{~mL}$ of isotonic phosphate buffer $\mathrm{pH}$ 6.8. The release was performed at $37 \pm 0.5{ }^{\circ} \mathrm{C}$, at a rotation speed of $50 \mathrm{rpm}$. One side of the buccal patch was attached to a glass disk with instant adhesive (cyanoacrylate). The disk was put in the bottom of the dissolution vessel so that the patch remained on the upper side of the disk. Samples $(5 \mathrm{~mL})$ were withdrawn at pre-determined time intervals and replaced with fresh medium. The samples were filtered through $0.45 \mu \mathrm{m}$ Whatman filter paper with appropriate dilutions with phosphate buffer $\mathrm{pH} 6.8$ and were assayed spectrophotometrically at $290 \mathrm{~nm}(20)$.

\section{In vitro buccal permeation study}

The in vitro study of propranolol hydrochloride permeation through the sheep buccal mucosa was performed using a Keshary-Chien type glass diffusion cell at $37 \pm 0.2^{\circ} \mathrm{C}$. Sheep buccal mucosa was obtained from a local slaughterhouse (used within $2 \mathrm{~h}$ of slaughter). Freshly obtained sheep buccal mucosa was mounted between the donor and receptor compartments so that the smooth surface of the mucosa faced the donor compartment. The patch was placed on the mucosa and the compartments clamped together. The donor compartment was filled with $1 \mathrm{~mL}$ of isotonic phosphate buffer $\mathrm{pH}$ 6.8. The 
V. M. Patel et al:: Design and characterization of chitosan-containing mucoadhesive buccal patches of propranolol hydrochloride, Acta Pharm. 57 (2007) 61-72.

receptor compartment ( $15 \mathrm{~mL}$ capacity) was filled with isotonic phosphate buffer $\mathrm{pH} 7.4$ and the hydrodynamics in the receptor compartment was maintained by stirring with a magnetic bead at $100 \mathrm{rpm}$. One mL sample was withdrawn at predetermined time intervals and analyzed for drug content at $290 \mathrm{~nm}(20)$.

\section{Stability in human saliva}

The stability of optimized patches was tested in natural human saliva with the approval of the Ethical Committee on 10 volunteers. Human saliva was collected from healthy volunteers (aged 18-50 years, male and female), free of any disease. Patches were placed in separate Petri dishes containing $5 \mathrm{~mL}$ of human saliva and kept in a temperaturecontrolled oven (Hicon, Groover Enterprises, India) at $37 \pm 0.2^{\circ} \mathrm{C}$ for $6 \mathrm{~h}$. At regular time intervals $(0,1,2,3$ and $6 \mathrm{~h})$, the patches were examined for changes in color and shape, collapse of the patch. Drug content was determined by appropriate dilution of human saliva in phosphate buffer pH 6.8 and analyzed by spectrophotometry at $290 \mathrm{~nm}$ (20).

\section{RESULTS AND DISCUSSION}

In the present study, buccal patches for controlled delivery of propranolol hydrochloride were developed using chitosan as the base matrix. The patches were prepared using different ratios of chitosan to PVP K-30 (1:0.1, 1:0.15, 1:0.175, 1:0.2 and 1:0.225 from batch F1 to F6. PVP K-30 was added to improve the drug release by polymer swelling, elasticity and film forming properties of the patches. Propylene glycol (5\%) was added as plasticizer. On the basis of bioadhesive strength $(9.6 \pm 2.0 \mathrm{~g})$ and in vitro drug release $(85.5 \%$ in $7 \mathrm{~h})$ from the buccal patches, batch F4 was selected for further study. Batch F7 was prepared from optimized batch (F4) by taking half quantity of the drug to study the effect of drug concentration in buccal formulations.

The prepared patches were smooth in appearance, uniform in thickness, mass, and drug content and showed no visible cracks. The patches exhibited good folding endurance (more than 150, Table III). Patch thickness ranged from $0.43 \pm 0.01$ to $0.58 \pm 0.04 \mathrm{~mm}$ and mass ranged from $68 \pm 1$ to $84 \pm 1 \mathrm{mg}$. Patches had a surface $\mathrm{pH}$ of $5.82 \pm 0.13$ to 6.11 \pm 0.12 . The drug content in the buccal patches ranged from $98.9 \pm 1.1$ to $100.4 \pm 0.4 \%$, indicating the favourable drug loading and patches uniformity with respect to drug content.

Appropriate swelling behavior of a buccal adhesive system is the essential property for uniform and prolonged release of the drug and effective mucoadhesion (25). The swelling study indicated that the swelling index was higher in patches containing a higher amount of PVP K-30. Examination of the patches during the dissolution studies also revealed that the patches showed considerable swelling, especially at higher concentrations of PVP K-30. The weak aqueous solubility of the cationic polymer (chitosan) limited the swelling of the patches, which was observed in placebo patches. Addition of the hydrophilic polymer PVP K-30 increased the surface wettability and consequently water penetration within the matrix. 
V. M. Patel et al:: Design and characterization of chitosan-containing mucoadhesive buccal patches of propranolol hydrochloride, Acta Pharm. 57 (2007) 61-72.

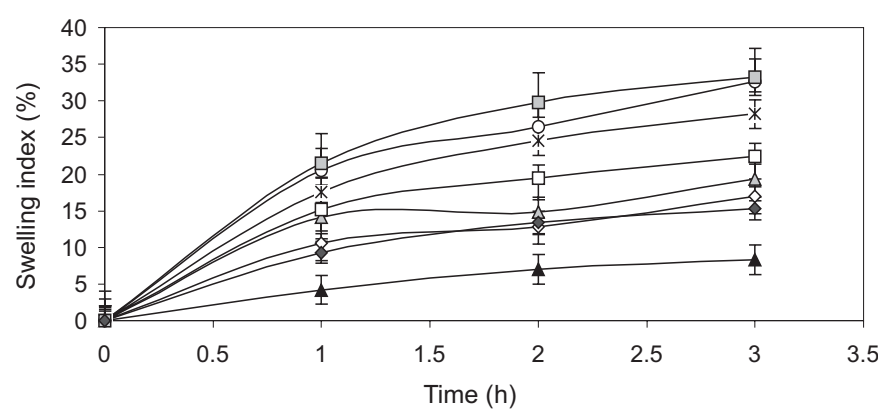

placebo $\diamond-\mathrm{F} 1 \multimap-\mathrm{F} 2 \multimap-\mathrm{F} 3-*-\mathrm{F} 4 \multimap-\mathrm{F} 5 \multimap \square-\mathrm{F} 6 \multimap-\mathrm{F} 7$
Fig. 1. Swelling index of buccal patches from batches F1 to F7. Mean $\pm \mathrm{SD}, n=3$.

Patches did not show any appreciable changes in their shape and form during the $3 \mathrm{~h}$ that they were kept on a $2 \%$ agar gel plate. The optimized patch (F4) showed a 28.2 $\pm 1.2 \%$ swelling index due to water absorption within $3 \mathrm{~h}$. Swelling behavior of patches as a function of time is shown in Figure 1. It was observed that medicated patches had a higher swelling index compared to plain patches. The higher swelling index of medicated patches may be due to the hydrophilic nature of the drug, which dissolves fast when it comes in contact with the dissolution medium. Figure 2 shows that patches containing PVP (batches F1 to F6) had a higher swelling index than the patches without PVP.

Mucoadhesion may be defined as the adhesion between a polymer and mucus. In general, mucoadhesion is considered to occur in 3 major stages: wetting, interpenetration, and mechanical interlocking between mucus and polymer. The strength of mucoadhesion is affected by various factors such as molecular mass of polymers, contact time with mucus, swelling rate of the polymer and the biological membrane used in the study (26). In this study, sheep buccal mucosa was used as biological membrane. Plain patches showed higher mucoadhesive strength $(21.5 \pm 1.8 \mathrm{~g})$ than medicated patches. The patch containing $10 \mathrm{mg}$ of drug (F7) showed higher bioadhesive strength compared to $20 \mathrm{mg}$

Fig. 2. Cumulative drug released from batches F1 to F7. Mean \pm SD, $n=3$.

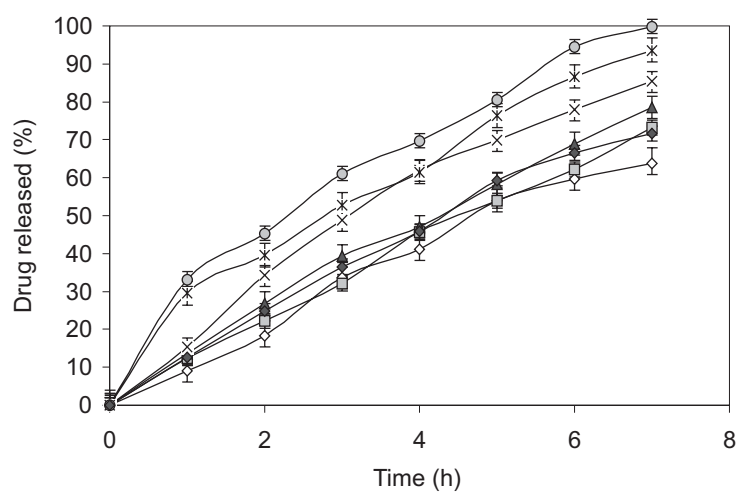

$\leadsto$ F1 $\square-F 2 \multimap F 3-x-F 4-*-F 5 \multimap$ F6 $\leadsto$ F7 
V. M. Patel et al.: Design and characterization of chitosan-containing mucoadhesive buccal patches of propranolol hydrochloride, Acta Pharm. 57 (2007) 61-72.

of drug (F1 to F6). Incorporation of PVP K-30, a water-soluble hydrophilic polymer, and water-soluble drug reduced significantly the bioadhesive strength of buccal patches. Bioadhesive strength of the optimized patch (F4) was found to be $9.6 \pm 2.0 \mathrm{~g}$ and the force of adhesion and bond strength were $0.0942 \mathrm{~N}^{2}$ and $468.75 \mathrm{~N} \mathrm{~m}^{-2}$, respectively. The important bioadhesive parameters of buccal patches are given in Table II.

In vitro release of propranolol hydrochloride from different patches is shown in Figure 2. The drug released increased linearly with the increasing concentration of PVPK-30 from batches F1 to F6. The maximum in vitro release was found to be $99.8 \pm 1.3 \%$ over a period of $7 \mathrm{~h}$ in batch F6, containing the highest amount of PVP K-30, which could be attributed to its high rate and extent of swelling. This finding was also supported by the results of swelling studies where the highest swelling index was also exhibited by batch F6, indicating that the increase in water-soluble polymer PVP-K30 content results in faster swelling and release from patches (27).

F4 patches with $20 \mathrm{mg}$ of drug showed higher and faster drug release than patches containing $10 \mathrm{mg}$ of drug (F7). Propranolol hydrochloride (a water soluble drug), dissolves easily in a hydrated polymeric environment. Therefore, the higher the loading of propranolol hydrochloride, the more drug would dissolve inside the hydrated matrices, resulting in a higher diffusional driving force and faster drug release. These results showed that the drug and PVP K-30 have also a significant effect on release behaviour of the drug from chitosan-based matrix. The release data were analyzed using the well known semi-empirical Peppas equation (28):

$$
M_{t} / M_{\infty}=k t^{n}
$$

where $M_{t} / M_{\infty}$ is the fractional release of the drug, $t$ denotes the release time, $k$ represents a kinetic constant, incorporating structural and geometrical characteristics of the device, and $n$ is the diffusional exponent and characterizes the type of release mechanism during the dissolution process. For non-Fickian release, the value of $n$ falls between 0.5 and 1.0 while in the case of Fickian diffusion $n=0.5$; for first order release (case II transport) $n=1$, and for supercase II transport $n>1$. The obtained values of $k, n$ and $R^{2}$ (coefficient determination) are presented in Table IV. The values of $n$ were estimated by

Table IV. Kinetic constant (k), release exponent $(\mathrm{n})$ and determination coefficient $\mathrm{R}^{2}$

\begin{tabular}{lccc}
\hline \multirow{2}{*}{ Batch } & \multicolumn{1}{c}{ Peppas model } \\
\cline { 2 - 4 } & $k\left(\% \mathrm{~h}^{-1}\right)$ & $R^{2}$ & $n$ \\
\hline F1 & 0.1722 & 0.9685 & 0.666 \\
F2 & 0.1928 & 0.988 & 0.684 \\
F3 & 0.1986 & 0.9925 & 0.7036 \\
F4 & 0.2023 & 0.9937 & 0.7365 \\
F5 & 0.2104 & 0.9952 & 0.7633 \\
F6 & 0.2163 & 0.9927 & 0.7821 \\
F7 & 0.1841 & 0.9897 & 0.6942 \\
\hline
\end{tabular}


V. M. Patel et al:: Design and characterization of chitosan-containing mucoadhesive buccal patches of propranolol hydrochloride, Acta Pharm. 57 (2007) 61-72.

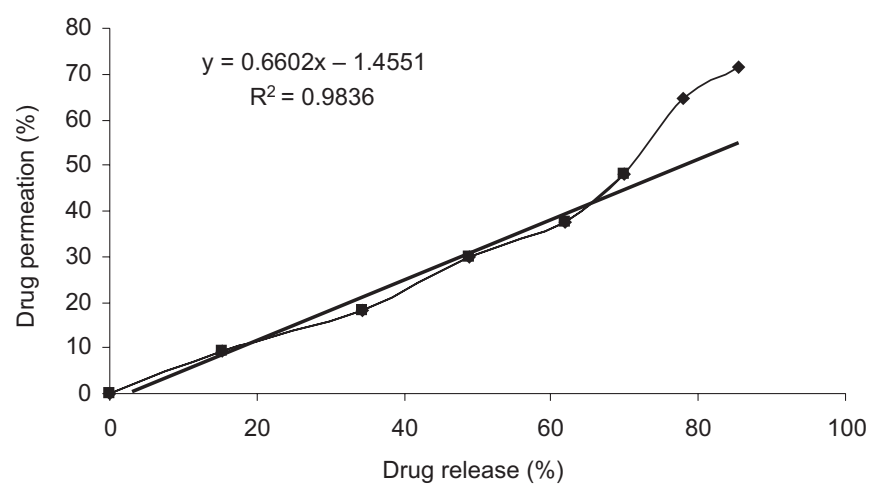

Fig. 3. Correlation between in vitro drug release and in vitro drug permeation.

linear regression of $\log \left(M_{t} / M_{\infty}\right)$ vs. $\log t$, and were between 0.5 and 1.0 , indicating that the release of propranolol hydrochloride was by non-Fickian diffusion. In the kinetics study, the order of drug release from all batches followed zero-order kinetics.

The surface $\mathrm{pH}$ of the patches was determined in order to investigate the possibility of any side effects, in vivo. Since an acidic or alkaline $\mathrm{pH}$ may cause irritation to the buccal mucosa, we attempted to keep the surface $\mathrm{pH}$ as close to neutral as possible. The surface $\mathrm{pH}$ of all the patches (F1 to F7) was near 6 and hence, these patches should not cause any irritation in the buccal cavity. Ex vivo mucoadhesion time for the medicated patches varied from 165 to 430 minutes (Table III), the plain patches showed longer mucoadhesion time (705 minutes). Incorporation of PVP K-30 and the drug reduced significantly ex vivo mucoadhesion time of the patches. Optimized patches (F4) showed a 272 minutes mucoadhesion time on sheep buccal mucosa.

F4 patches were characterized by moderate swelling, a convenient residence time as well as adequate drug release. These patches were subject to investigation of in vitro drug diffusion and stability in human saliva. They showed $71.7 \%$ drug permeation in $7 \mathrm{~h}$ through sheep buccal mucosa. Good correlation was observed between in vitro drug release and in vitro drug permeation with a correlation coefficient of 0.96 (Fig. 3).

Stability studies are usually performed in phosphate buffer solutions whose $\mathrm{pH}$ pertains to the buccal cavity, but stability studies performed in normal human saliva would

Table V. Stability study of optimized chitosan buccal patches (batch F4) in human saliva

\begin{tabular}{lccc}
\hline Sampling time $(\mathrm{h})$ & Thickness $(\mathrm{mm})^{\mathrm{a}}$ & Diameter $(\mathrm{mm})^{\mathrm{a}}$ & ${\text { Drug recovered }(\%)^{\mathrm{a}}}^{\mathrm{a}}$ \\
\hline 0 & $0.56 \pm 0.06$ & $16.0 \pm 0.10$ & $99.9 \pm 0.1$ \\
1 & $0.56 \pm 0.08$ & $16.1 \pm 0.10$ & $99.2 \pm 0.3$ \\
2 & $0.57 \pm 0.07$ & $16.2 \pm 0.04$ & $99.2 \pm 0.4$ \\
3 & $0.60 \pm 0.02$ & $16.3 \pm 0.03$ & $99.5 \pm 0.3$ \\
6 & $0.60 \pm 0.04$ & $16.5 \pm 0.10$ & $99.1 \pm 0.5$ \\
\hline
\end{tabular}

\footnotetext{
a Mean \pm SD, $n=3$.
} 
be more appropriate to mimic the stability of drug and device in the oral cavity in vivo. Therefore, the stability study of optimized patches (F4) was examined in human saliva and their appearance characteristics, such as color and shape, and drug content in natural human saliva were evaluated (Table V). Thickness and diameter of patches increased to 7.1 and $3.1 \%$ owing to swelling in human saliva in $6 \mathrm{~h}$ studies. No color changes were observed. The recovery of the drug from all patches was found to be $99.9 \pm 0.1 \%$ indicating maximum utilization of the drug incorporated.

\section{CONCLUSIONS}

From the present investigation, one can conclude that the optimized buccoadhesive patches of propranolol hydrochloride with the combination of chitosan and PVP K-30 can meet the ideal requirements for buccal devices, which can be a good way to bypass the extensive hepatic first pass metabolism.

\section{REFERENCES}

1. A. J. Hoogstraate, J. C. Verhoef, B. Tuk, A. Pijpers, L. A. M. G. van Leengoed, J. H. M. Verheijden, H. E. Junginger and H. E. Bodde, In vitro buccal delivery of fluorescein isothiocyanate dextran 4400 with glycodeoxycholate as an absorption enhancer in pigs, J. Pharm. Sci. 85 (1996) $457-460$.

2. J. Ali, R. K. Khar and A. Ahuja, Formulation and characterization of a buccoadhesive erodible tablet for the treatment of oral lesions, Pharmazie 53 (1998) 329-334.

3. Y. Kohda, H. Kobayashi, Y. Baba, H. Yuasa, T. Ozeki, Y. Kanaya and E. Sagara, Controlled release of lidocaine hydrochloride from buccal mucosa-adhesive films with solid dispersion, Int. J. Pharm. 15 (1983) 147-155.

4. M. M. Nair and Y. W. Chien, Development of anticandidal delivery systems. (II) Mucoadhesive devices for prolonged drug delivery in the oral cavity, Drug Dev. Ind. Pharm. 22 (1996) 243-253.

5. B. Parodi, E. Russo, G. Caviglioli, S. Cafaggi and G. Bignardi, Development and characterization of a buccoadhesive dosage form of oxycodone hydrochloride, Drug Dev. Ind. Pharm. 22 (1996) $445-450$.

6. R. Hango, S. Kavimani, A. R. Mullaicharam and B. Jayakar, In vitro studies on buccal strips of glibenclamide using chitosan, Ind. J. Pharm. Sci. 59 (1997) 232-235.

7. K. D. Bremecker, H. Strempel and G. Klein, Novel concept for a mucosal adhesive ointment, J. Pharm. Sci. 73 (1984) 548-552.

8. S. C. Shin, J. P. Bum and J. S. Choi, Enhanced bioavailability by buccal administration of triamcinolone acetonide from the bioadhesive gels in rabbits, Int. J. Pharm. 209 (2000) 37-43.

9. J. M. Gu, J. R. Robinson and S. H. S. Leung, Binding of acrylic polymers to mucin/epithelial surfaces: Structure-property relationships, CRC Crit. Rev. Ther. Drug Carrier Systems 21 (1988) 21-67.

10. C. M. Lehr, J. A. Bouwstra, E. H. Schacht and H. E. Junginger, In vitro evaluation of mucoadhesive properties of chitosan and some other natural polymers, Int. J. Pharm. 78 (1992) 43-48.

11. R. A. A. Muzarelli, Chitin, Pergamon Press, Oxford 1977.

12. S. Hirano, H. Seino, I. Akiyama and I. Nonaka, Chitosan a Biocompatible Material for Oral and Intravenous Administrations: Progress in Biomedical Polymers, Plenum Press, New York 1990, pp. 283- 289. 
V. M. Patel et al.: Design and characterization of chitosan-containing mucoadhesive buccal patches of propranolol hydrochloride, Acta Pharm. 57 (2007) 61-72.

13. T. Nagai, Y. Sawayanagi and N. Nambu, Application of Chitin and Chitosan to Pharmaceutical Preparations: Chitin, Chitosan and Related Enzymes, Academic Press, Orlando 1984, pp. 21-39.

14. K. Inouye, Y. Machida, T. Sannan and T. Nagai, Buoyant sustained release tablets based on chitosan, Drug Des. Deliv. 2 (1988) 165-175.

15. C. Ramunan-Lopez and R. Bodmeier, Mechanical and water vapor transmission properties of polysaccharide films, Drug Dev. Ind. Pharm. 22 (1996) 1201-1209.

16. B. B. Hoffman and R. J. Lefkowitz, Goodman and Gillman's: The Pharmacological Basis of Therapeutics, $9^{\text {th }}$ ed., Mc Graw-Hill, New Delhi 1994, pp. 128-130.

17. Y. Sawayanaga, N. Nambu and T. Nagai, Permeation of drugs through chitosan membranes, Chem. Pharm. Bull. 30 (1982) 3297-3301.

18. R. Khurana, A. Ahuja and R. K. Khar, Development and evaluation of mucoadhesive films of miconazole nitrate, Indian J. Pharm. Sci. 60 (2000) 449-453.

19. J. Kemken, A. Ziegler and B. W. Muller, Pharmacodynamic effects of transdermal bupranolol and timolol in vivo: comparison of micro emulsions and matrix patches as vehicles, Math. Find. Exp. Clin. Pharmacol. 13 (1991) 361-365.

20. Pharmacopoeia of India, $3^{\text {rd }}$ ed., Controller of Publications, New Delhi 1996, p. 634.

21. A. Gupta, S. Garg and R. K. Khar, Measurement of bioadhesive strength of muco-adhesive buccal tablets: design of an in vitro assembly, Indian Drugs 30 (1992) 152-155.

22. R. Y. Han, J. Y. Fang, K. C. Sung and O. Y. P. Hu, Mucoadhesive buccal disks for novel nalbuphine prodrug controlled delivery: effect of formulation variables on drug release and mucoadhesive performance, Int. J. Pharm. 177 (1999) 201-209.

23. P. Bottenberg, R. Cleymaet, C. D. Muynek, J. P. Remon, D. Coomans and D. Slop, Development and testing of bioadhesive, fluoride containing slow-release tablets for oral use, J. Pharm. Pharmacol. 43 (1991) 457-464.

24. USP, 23/NF 18, USP Convention, Rockville 1995, pp. 1792-1795.

25. N. A. Peppas and P. A. Bury, Surface interfacial and molecular aspects of polymer bioadhesion on soft tissues, J. Control Rel. 2 (1985) 257-275.

26. H. Park and J. R. Robinson, Mechanisms of bioadhesion of poly(acrylic acid) hydrogels, Pharm. Res. 4 (1987) 457-464.

27. R. W. Korsmeyer, R. Gurny, E. Doelker, P. Buri and N. A. Peppas, Mechanisms of solute release from porous hydrophilic polymers, Int. J. Pharm. 15 (1983) 25-35.

28. N. A. Peppas, Analysis of Fickian and non-Fickian drug release from polymers, Pharm. Acta Helv. 60 (1985) 110-111.

\section{Priprava i karakterizacija mukoadhezivnih flastera za bukalnu primjenu propranolol hidroklorida s kitozanom}

VISHNU M. PATEL, BHUPENDRA G. PRAJAPATI i MADHABHAI M. PATEL

Mukoadhezivni flasteri za bukalnu primjenu s propranolol hidrokloridom pripravljeni su koristeći metodu isparavanja otapala. Kao mukoadhezivni polimer upotrebljen je kitozan u različitim omjerima u odnosu na PVP K-30. Određivana su sljedeća svojstva flastera: masa, ujednačenost količine lijeka, savitljivost, ex vivo mukooadhezivnost, ex vivo vrijeme mukoadhezije, $\mathrm{pH}$ na površini, in vitro oslobađanje ljekovite tvari i in vitro 
V. M. Patel et al:: Design and characterization of chitosan-containing mucoadhesive buccal patches of propranolol hydrochloride, Acta Pharm. 57 (2007) 61-72.

permeacija. Iz flastera se ljekovita tvar kontrolirano oslobađala, prema kinetici prvog reda tijekom 7 h i nije slijedila Fickov zakon difuzije. Upotreba PVP K-30 produljila je vrijeme oslobađanja. Indeks bubrenja bio je proporcionalan koncentraciji PVP K-30. Snaga bioadhezije optimiranih flastera (F4) bila je $9,6 \pm 2,0 \mathrm{~g}$, a ex vivo vrijeme mukoadhezije 272 minute. $\mathrm{pH}$ na površini svih flastera bio je između 5,7 i 6,3 pa ne bi trebali iritirati bukalnu šupljinu. Flasteri sa $10 \mathrm{mg}$ propranolola imali su veću bioadhezivnost, a lijek se iz njih polaganije oslobađao nego iz flastera sa $20 \mathrm{mg}$ ljekovite tvari. Dobivena je dobra korelacija između in vitro oslobađanja i in vitro permeacije lijeka (koeficijent korelacije 0,9364). Ispitivanja stabilnosti pokazala su da su i propranolol i flasteri za bukalnu primjenu stabilni u ljudskoj slini.

Ključne riječi: mukoadhezija, flasteri za bukalnu primjenu, propranolol hidroklorid, bukalna primjena, kitozan

S. K. Patel College of Pharmaceutical Education and Research, Ganpat Vidyanagar, Kherva-382711 Mehsana, Gujarat, India 